\title{
Climate change and its impact on livestock: A review
}

Saka, A. A., Awodola-Peters, O. O., Olaniyi, T. A., Adedeji, O. Y., Bolarinwa, M. O., Yahaya, M. O., Adebisi, G. L. and Popoola, M. A.

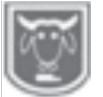

${ }^{1}$ Federal College of Animal Health and Production Technology,

P. M. B. 5029, Moor Plantation, Ibadan.

Abstract

Corresponding author: saka.azeez@gmail.com

As the demand for livestock products is on the increase due to improved standard of living, the fear of its negative effect of climate is also on the increase. The impact of climate change on livestock production was reviewed in this study. Livestock through contributes to the emissions which in turn has negative impact on livestock production. Humans, animals and mixed farming, produce emissions which contribute so much to the change in climate. Heat stress associated with climate change has an enormous effect on poultry production as it affects chicken growth and productivity as poultry meat and eggs play an important food security role across Africa and world at large. Understanding how farmers deal with the realities of poultry production due to climate change is critical. In pig production the influence of climate change may differ slightly depending on the breed types and locality but common problems are lack of water, pests and diseases, death of the animal at extreme heat stress and possible alteration in grazing behavior which will lead ultimately to decrease in feed intake and feed digestibility and efficiency offeed utilization which can be seen in terms of growth, pork yield and milk production. Ruminants which are the primary producers of methane $\left(\mathrm{CH}_{4}\right)$ has many factors influencing these emissions such as level offeed intake, type of carbohydrate in the diet and feed processing. Manipulation of these factors can reduce methane emissions from cattle.

Keywords: Climate change, livestock production, methane.

\section{Le changement climatique et son impact sur le bétail: un bilan}

\section{Résumé}

$\overline{L a}$ demande de produits de bétail étant en agrandissement en raison de l'amélioration du niveau de vie, la crainte de son effet négatif sur le climat est également en augmentation. L'impact du changement climatique sur la production animale a été examiné dans cette étude. L'élevage contribue aux émissions qui à leur tour ont un impact négatif sur la production animale. Les humains, les animaux et l'agriculture mixte, produisent des émissions qui contribuent beaucoup au changement climatique. Le stress thermique associé au changement climatique a un effet énorme sur la production de volaille car il affecte la croissance et la productivité des poulets, car la viande et les oufs de volaille jouent un rôle important dans la sécurité alimentaire en Afrique et dans le monde en général. Il est essentiel de comprendre comment les agriculteurs gèrent les réalités de la production de volaille en raison du changement climatique. Dans la production porcine, l'influence du changement climatique peut différer légèrement selon le type de race et la localité, mais les problèmes courants sont le manque d'eau, les ravageurs et les maladies, la mort de l'animal en cas de stress thermique extrême et une éventuelle modification du comportement de pâturage qui entraînera finalement une diminution dans l'ingestion et la digestibilité des aliments et l'efficacité de l'utilisation des aliments qui peuvent être vus en termes de croissance, de rendement de porc et de production de lait. Les ruminants qui sont les principaux 
producteurs de méthane (CH4) ont de nombreux facteurs influençant ces émissions tels que le niveau de consommation alimentaire, le type de glucides dans l'alimentation et la transformation des aliments. La manipulation de ces facteurs peut réduire les émissions de méthane des bovins.

Mots clés: changement climatique, production animale, méthane.

\section{Introduction}

The demand for livestock products globally is expected to be doubled by 2050 and this is due to the improvement in standard of living of people worldwide. However, a threat to animal production is climate change because of the impact on feed quality, forage and crop, availability of water, diseases that affects livestock, reproduction and of course biodiversity. Moreover, the animal sector contributes about $14.5 \%$ of global greenhouse gas (GHG) emissions, which further drives climate change. Consequently, the livestock sector will be a major player in the mitigation of $\mathrm{GHG}$ emissions and improving global food security (Rojas-Downing et al., 2017). Livestock products are considered an essential agricultural commodity for global food security because they provide $17 \%$ and $33 \%$ of global kilocalorie and protein consumption respectively (Rosegrant et al., 2009). This sector contributes to the livelihoods of about one billion of the poorest population in the world and employs close to 1.1 billion people (Hurst et al., 2005). There is a growing demand for livestock products, and its rapid growth in developing countries has been deemed the "livestock revolution" (Wright et al., 2012). Global milk production is expected to increase from 664 million tonnes (in 2006) to 1077 million tonnes (by 2050), and meat production will double from 258 to 455 million tonnes (Alexandratos and Bruinsma, 2012). Livestock production is likely to be adversely affected by climate change, competition for land and water, and food security at a time when it is most needed (Thornton, 2010).

\section{Climate change as it affects animal production}

Livestock contributes $44 \%$ of the world's human-inducedmethane $\left(\mathrm{CH}_{4}\right)$ emissions through their normal digestive processes (enteric fermentation) and management of manure (Gerber et al., 2013). Enteric fermentation and manure account for about $80 \%$ of 52 agricultural emission sources (Steinfeld et al., 2006). During the animals' digestive process, enteric fermentation converts the feed consumed into digestible feed. Enteric fermentation releases a $\mathrm{CH}_{4}$ by-product through expiration (Beauchemin et al., 2009). Therefore, this by-product is regarded as an energy loss (Gerber et al., 2013). Feed composition and feed intake can vary enteric fermentation and hence methane emissions. Increasing the concentrate (high energy feeds containing cereal grains and oil meals) proportion in the animal diet can reduce methane emissions from the animal (Dourmad et al., 2008; Yan et al., 2000). Methane emissions vary depending on production systems and factors like climate and environment (Gerber et al., 2013). The enteric fermentation produced by ruminant livestock (e.g. cattle, sheep, and goat) emits globally between 87 and 94 Terra grams (Tg) of methane annually (IPCC, 2013). Mixed crop-livestock systems account for $64 \%$ of global enteric fermentation methane emissions; grazing systems account for $35 \%$, and industrial 1\% (Steinfeld et al., 2006). The high percentage from mixed crop-livestock systems reflects that twothirds of total livestock animals are present in those systems (Steinfeld et al., 2006). In Africa, methane emissions are expected to 
elevate due to increase in livestock populations. Herrero et al. (2008) estimated that African cattle, goats, and sheep, which produced about 7.8 million tonnes of methane in 2000, are likely to increase to 11.1 million tonnes by 2030. If this linear relationship between methane emissions and livestock population continues, global methane emissions from livestock production may increase $60 \%$ by 2030 (Bruinsma, 2003). However, changing feeding practices and manure management could moderate methane emissions (Thornton and Herrero, 2010). Animals that contribute the most to livestock GHG emissions are beef and dairy cattle, accounting for $65 \%$ of the total livestock GHG emissions (Gerber et al., 2013). Pigs, poultry, buffaloes, and small ruminants contribute about 7 to $10 \%$. If $\mathrm{GHG}$ emissions are estimated based on commodities, beef cattle contribute the most with $41 \%$ of the sector's emission, followed by dairy cattle $(20 \%)$, swine $(9 \%)$, buffalo $(8 \%)$, poultry $(8 \%)$, and small ruminant (Gerberet al., 2013). Enteric fermentation is the largest source of GHG emissions from cattle, buffalo, and small ruminants, comprising between $43 \%$ and $63 \%$ of the livestock sector emissions. However, for pigs and chickens the largest source of emissions is due to feed production (between $25 \%$ and $27 \%$ ), which includes fertilizer production, machinery use, and feed transportation. Enteric fermentation from pigs is much lower than in ruminants because their digestive process does not produce as much methane as a byproduct (Gerber et al., 2013).

\section{Climate change and the poultry industry}

Poultry productions have minute impact on land and energy use, as well as global warming potential (Davies et al., 2010) when compared with beef and pork production. This is majorly because of its high efficiency in converting feed into meat (William et al., 2016). Although the poultry production generates smaller impacts than other livestock, it is a recognized pollution source due to the large generation of manure and consumption of grain for animal feed (Cherubini et al., 2015). Africa has been identified as a key driver of global meat consumption growth in the next few decades and for which domestic production must play an important role (The Economist, 2019). With its high rate of urbanization and increasing incomes, Nigeria's increasing demand for animal proteins has been accompanied by a rapid domestic supply response. Between 1980 and 2008, the country experienced a twofold increase in its poultry production and the share of maize allocated to animal feed increased in volume by $300 \%$ between 2003 and 2015 (Liverpool-Tasie et al., 2017). The expansion of the poultry industry in Nigeria has been attributed to the low cost of production and low barriers to entry for poultry production compared with other livestock products (Heise et al., 2015). The recent rapid growth of the poultry industry has translated into about 85 million Nigerians being involved in poultry production (many on a small or medium scale) and over 14 million people benefitting from employment in the increasingly commercialized sector (PAN 2017). Currently, the sector serves as an important source of employment and an affordable animal protein (particularly from eggs) for the country's large and growing population that is increasing its consumption of poultry products (Zhou and Staatz, 2016; United Nations, 2017). Though not as visible in the literature, poultry and other livestock farmers are already experiencing the adverse effects of climate change. For example, studies have demonstrated that pastoralists and livestock farmers across Africa have associated changes in temperature and rainfall patterns with reduced feed sources, increased animal mortality, lower herd sizes, reduced water 
sources in the dry season, decreased animal productivity, and the occurrence of new animal diseases (Ayanlade et al., 2017). Heat stress associated with climate change is an enormous challenge to poultry farmers due to its negative effect on chicken growth and productivity. As poultry plays an important food security role across Africa (being a source of livelihood and an important source of animal protein), understanding how farmers deal with the realities of poultry production due to climate change is critical (Saweda et al., 2019).

\section{Climate change and its effect on pig production}

In livestock industry, pig production precisely, the influence of climate change differ slightly (depending on the breed types, locality etc), but the commonly reported problems are lack of portable water for the animal's use, incidence of diseases and pests, extinction of the animal at extreme heat stress condition, alteration in grazing behavior (Johnson et al., 2015) decrease in feed intake and feed digestibility and efficiency of feed utilization (which can be measured in terms of growth, pork and milk production) (Hatfield, 2008). Other affects widely reported by scholars (Falusi and Adeleye, 1999; IPCC 2001; Scott and Edward, 2005) are low pork carcass quality, increase in frequency of parasite and decline in the storage and handling of animal products. The impacts of climate change on pig, just like other livestock are as result of an increase in temperature and atmospheric carbon dioxide $\left(\mathrm{CO}_{2}\right)$ concentration, precipitation variation, and a combination of these factors (Baker, 2004; John, 2007) Among the above factors, it is of paramount importance to state that temperature is a critical factor that thwarts most pig production through its water availability, production, reproduction and health (Bellarby et al., 2013).
Water is vital in pig metabolism and in wallowing under severe high temperature (Bradshain et al., 2004; FAO, 2007). Salination as result of sea riseis capable of affecting animal metabolism, fertility, and digestion in general (Stahly et al., 2011). Studies show that salination adds to chemical and biological contaminants and high concentrations of heavy metals could impair cardiovascular, excretory, skeletal, nervous and respiratory systems, and impair hygienic quality of production (Valtorta et al., 2012). The increase in temperature is capable of causing growth of pathogens and parasites that live outside of their host, resulting in poor performances of livestock (Adeshinwa et al., 2003). Global warming and changes in precipitation affect the quantity and spread of vector-borne pests such as flies, ticks, and mosquitoes especially under warmer condition (Casey et al., 2008). In addition, under warmer atmospheric temperature, there is higher disease transmission between hosts. Heat stress is one of the major concerns in pork production, since pigs do not have functional sweat glands like other livestock species in order to assist them in efficiently discharging of body heat. Pigs have a range of ambient environmental temperatures (a thermal comfort zone) that are important for physiological functions. Heat stress on pig is dependent on temperature, humidity, species, genetic potential, life stage, and nutritional status (Gerber et al., 2013).

Adaptation of ruminant livestock production systems to climate changes Climate change is a global concern threatening the forage availability, declining the potential of livestock production and subsequently influencing the live style of people (Vaclav, 2003). Ruminant livestock make a positive contribution to food security and well-being of communities by providing manure and draught power for other agricultural production. The ability of ruminants to 
convert ligno-cellulose to meat and milk that are sources of high-quality protein and essential nutrients contributes significantly to human health. More so, ruminant agriculture is arguably one of the food and fibre production systems most vulnerable to climate changes. Much of the rangelands meant to feed ruminant animals are sensitive to the impacts of climate changes. Global food security and the growing demand for animal products related to rising population and increasing income emphasis the importance of climate adaptation strategies to minimize adverse impacts on animal production. Mottet et al. (2017) reported that ruminant animals produce an estimated 36,355 Mt of protein per year and provide micronutrients essential for human well-being. Much of the production is in extensive rangelands where inputs are low, and forage production and water supply vary with seasonal climate. Livestock is also a reliable source of income from household to national scales. However, maintenance or growth of the sector to meet future demand for products and services provided by ruminant livestock must be balanced against a need to manage the welldocumented environmental impacts and potential for negative consequences for global food security. Prolonged drought influenced by climate change is one of the most serious climatic hazards affecting the agricultural sector. As most of the agricultural activities in Nigeria hinge on rain, any adverse changes in the climate would likely have a devastating effect on the sector. Global warming is projected to have significant impacts on conditions affecting livestock, including temperature, carbon dioxide, glacial run-off, precipitation and the interaction. Water intake by livestock is related to animal size, age, moisture content of diet, animal activity, temperature and physiological status of animals. Higgins et al. (2008) recommended drinking water for cattle should be between $5^{\circ} \mathrm{C}$ and $18^{\circ} \mathrm{C}$ and noted that when the ambient temperature exceeded $27^{\circ} \mathrm{C}$, water and feed intake decreased negatively affecting animal productivity. It has been estimated that cattle will require $13 \%$ more water for a temperature increase of $2.7^{\circ} \mathrm{C}$ in a subtropical region (Harle et al., 2007). In response to global warming, adaptation strategies will be needed to meet the requirements, in terms of both quantity and temperature, for both productivity and welfare of ruminants. Adaptation strategies for changes in water availability and water needs may include both infrastructure and management options. Projected precipitation and evapotranspiration rates support forward planning for increased investment in storage tanks and dams. New dams and catchments need to be designed to better cope with future demand and for less evaporative loss. In rangelands increasing the number of watering points will reduce the distance animals have to walk to drink and will have the co-benefit of encouraging more even pasture utilization. In extensive systems, including shade over watering points will reduce evaporative loss, reduce water temperatures, increase the efficacy of water intake by animals and thus assist with reducing heat stress (Gaughan et al., 2010). In intensive production such as dairy or feedlot cattle systems increasing effluent and water re-use for wash-down and irrigation will improve resource efficiency and assist adaptation. Ruminant livestock are the primary producers of methane $\left(\mathrm{CH}_{4}\right)$. They can produce 250 to 500 liters of methane per day (Olijhoek and Lund 2017). This level of production results in estimates of the contribution by cattle to global warming which is very high. Many factors influence these methane emissions from cattle. This includes like, level of feed intake, type of carbohydrate in the diet, feed processing, etc. Manipulation of these factors can reduce methane emissions from 
cattle. Ruminal digestion of feed by the microorganisms, under anaerobic results in the production of acetate, propionate and butyrate, which are used by the animal as energy source, and the production of carbon dioxide $\left(\mathrm{CO}_{2}\right)$ and $\mathrm{CH}_{4}$ which are eliminated through eructation (Martin et al., 2009). These gases are produced in the rumen by the process of methanogenesis. It is a process besides its negative impact on the environment, representing a loss of 2$15 \%$ of gross energy intake (Guo et al., 2008) for the animal, leading to an unproductive use of dietary energy (Kim et al., 2012).

\section{Conclusion}

Livestock production system is being affected by climate change and at the same time contributes to climate change, it has the potential to be an increasingly formidable constraint to the development of the livestock production. Responding to this challenge requires formulation of appropriate adaptation strategies and mitigation options. Factors affecting variability in enteric $\mathrm{CH}_{4}$ production requires urgent attention and efforts to decrease the uncertainty in GHG emission inventories. It is very essential to identify viable GHG reduction strategies. First, much more clarity is needed concerning the benefits of livestock, the negative impacts they can have on greenhouse-gas emissions and the environment, and the effects of climate change on livestock system. Although the reduction in GHG emissions from livestock industries are seen as high priorities, strategies for reducing emissions should not reduce the economic viability of enterprises. If the climate change continues as the present it will have devastating effect on livestock, farmers and communities who overwhelmingly depend on livestock for their livelihood and sustainability. Thus, for sustainable livestock production, there is a need for policies that support the implementation of climate change adaptation and mitigation measures.

\section{References}

Adeshinwa, A. O. K., Makinde, G. E.O. and Oladele, I. O. 2003. Demographic Characteristics of Pig Farmers as Determinant of Pig Feeding Pattern in Oyo State, Nigeria. Proceeding 8th Annual Conference of Animal Science Association (ASAN), September 16182003 in Federal University of Technology, Owerri Imo state Nigeria.

Alexandratos, N. and Bruinsma, J. 2012. World agriculture towards 2030/2050: the 2012 revision. ESA Working paper No. 12-03. FAO, Rome

Ayanlade, A., Radeny, M. and AkinOnigbinde, A. I. 2018. Climate variability/change and attitude to adaptation technologies: a pilot study among selected rural farmers' communities in Nigeria. Geo Journal. 83:319-331

Baker, J. E. 2004. Effective Environmental Temperature. Journal of Swine Health and Production, 12(3):140143.

Beauchemin, K. A., McAllister, T. A. and McGinn, S. M. 2009. Dietary mitigation of enteric methane from cattle. CAB reviews: perspectives in agriculture, veterinary science. Nutr. Nat. Resour. 4 (35), 1-8.

Bradshain, J. F., Burton, I. and Smith, J. B. 2004. Measures of farm asset and Inventory in tropical countries. Department of Agricultural Economics and Farm Management, University of Ilorin, Kwara State, Nigeria, 2004.

Bruinsma, J. 2003. World Agriculture: Towards 2015/2030: An FAO Perspective. Earthscan, London.

Casey, K. D., Bicudo, R., Schmidt, D. R., 
Singh, S. W., Gay, R. S., Gates, L. D. and Jacobson, S. J. 2008. Air quality and emissions from livestock and poultry production/waste management systems; Animal Sci., 23(6):23-28.

Dourmad, J., Rigolot, C. and Van der Werf, H. 2008. Emission of Greenhouse Gas: developing management and animal farming systems to assist mitigation. In: Rowlinson, P., Steel, M., Nefzaoui, A. (Eds.), Livestock and Global Climate Change Conference Proceeding. Cambridge University Press, Tunisia, pp. 36-39

Falusi, A. O. and Adeleye, I. O. A. 1999. Agricultural Science for Senior Secondary Schools.

FAO. 2007. Adaptation to Climate Change in Agriculture, Forestry, and Fisheries Perspective Flam Work and Priorities.

Gaughan , J. B., Bonner, S., Loxton, I., Mader, T. L., Lisle, A. and Lawrence, R. 2010. Effect of shade on body temperature and performance of feedlot steers. Journal of Animal Science. 88: 4056-4067

Gerber, P. J., Steinfeld, H., Henderson, B., Mottet, A., Opio, C., Dijkman, J., Falcucci, A., Tempio, G. 2013. Tackling Climate Change Through Livestock: A Global Assessment of Emissions and Mitigation Opportunities. FAO, Rome.

Guo, Y. Q., Liu J. X., Lu Y., Zhu, W. Y. and Denman, S. E. 2008. Effect of tea Saponin on Methanogenesis, Microbial community structure and Expression of mcrA gene, in cultures of rumen microorganisms. Lett Appl Microbial., 47(5): 421-426.

Harle, K. J., Howden, S. M., Hunt, L. P. and Dunlop, M. 2007. The potential impact of climate change on the
Australian wool industry by 2030 . Agricultural Systems 93: 61-89.

Hatfield, J. L. 2008. The effects of climate change on livestock production. USDA's Agricultural Service $A R S$, 251-257.

Heise, H., Crisan, A. and Theuvsen, L. 2015. The poultry market in Nigeria: market structures and potential for investment in the market. Int Food AgribusManag Rev 18:197-222

Herrero, M., Thornton, P. K., Kruska, R. and Reid, R. S. 2008. Systems dynamics and the spatial distribution of methane emissions from African domestic ruminants to 2030. Agric. Ecosyst. Environ., 126, 122-137.

Higgins, S. F., Agouridis, C. T. and Gumbert, A. A. 2008. Drinking Water Quality Guidelines for Cattle. University of Kentucky Extension Service. Retrieved on 29 November $2017, \quad$ f r o m http://www2.ca.uky.edu/agc/pubs/id /id170/id170.pdf.

Hurst, P., Termine, P. and Karl, M. 2005. Agricultural workers and their contribution to sustainable agriculture and rural development. FAO,Rome

Intergovernmental Panel on Climate Change. 2001. Impacts, Adaptation and Vulnerability, Intergovernmental Panel on Climate Change; Cambridge University Press: Cambridge, UK,

Intergovermental Panel on Climate Change. 2013. Climate change 2013: The physical science basis. In: Stocker, T.F., Qin, D., Plattner, G.-K., Tignor, M., Allen, S.K., Boschung, J., Nauels, A., Xia, Y., Bex, V., Midgley, P.M. (Eds.), Contribution of Working Group I to the Fifth Assessment Report of the Intergovernmental Panel on Climate Change. Cambridge University 
Press, Cambridge, United Kingdom and New York, NY, USA, p. 1535.

John, R. M. 2007. Swine Production: A global perspective. U.S.A: AlltechInc,.

Johnson, J. S., Sanz Fernandez, M.V., Patience, J. F., Ross, J. W., Gabler, N. K., Lucy, M. C, Safranski, T. J., Rhoads, R. P. and Baumgard, L. H. 2015. Effects of in utero heat stress on postnatal body composition in pigs: II. Finishing Pigs. J. Anim. Sci. 23:56-67

Kim, E. T., Kim, C. H., Min, K. S. and Lee, S. S. 2012. Effects of plant extract on microbial population, methane emission and ruminal fermentation characteristics in in vitro. Asian-Aust J Anim Sci., 25: 806-811.

Liverpool-Tasie, L. S. O., Omonona, B., Sanou, A., Ogunleye, W., Padilla, S. and Reardon, T. A. 2017. Growth and transformation of food systems in Africa: evidence from the poultry value chain in Nigeria. Michigan State University Feed the Future Innovation Lab for Food Security

Martin, C., Morgavi, D. P. and Doreau, M. 2009. Methane mitigation in ruminants: from microbe to the farm scale. Journal of Animal Sci., 4(3): 351-365.

Olijhoek, D. and Lund, P. 2017. Methane production by ruminants. Department of Animal science AUFoulum. Aarhus University, Denmark.

PAN. 2017. History of the poultry association of Nigeria. Poultry Association of Nigeria, Abuja

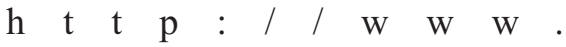
poultryassociationng.com/

Rojas-Downing, M. M., Nejadhashemi, A. P., Harrigan, T. and Woznicki, S. A. 2017. Climate change and livestock: Impacts, adaptation, and mitigation. Climate risk management $16,145-163$

Rosegrant, M. W., Fernandez, M. and Sinha, A. 2009. Looking into the future for agriculture and AKST. In: McIntyre, B.D., Herren, H.R., Wakhungu, J., Watson, R.T. (Eds.), International Assessment of Agricultural Knowledge, Science and Technology for Development (IAASTD). Agriculture at a crossroads, Island Press, Washington, DC, pp. 307-376.

Saweda, L., Liverpool-Tasie, O., Sanou, A. and Tambo, J. A. 2019. Climate change adaptation among poultry farmers: evidence from Nigeria. Climate change 157: 527-544

Scott, K. and Edwards, S. 2005. Environmental Enrichment for pigs. Pig Progress, 21(7):27-28

Stahly, T. S., Cromwell, G. L. and Overfield, G. L. 2011. Interactive effects of season of year and dietary fat supplementation, lysine source and lysine level on performance of swine. J. Anim. Sci. 53:1269-1277.

Steinfeld, H., Gerber, P., Wassenaar, T., Castel, V., Rosales, M. and Haan, C. 2006. Livestock's Long Shadow: Environmental Issues and Options. FAO, Rome.

The Economist. 2019. Global meat-eating is on the rise, bringing surprising benefits The Economist Magazine, May 4

Thornton, P. K. 2010. Livestock production: recent trends, future prospects. Philos. Trans. Roy. Soc. B 365, 2853-2867.

Thornton, P. K. and Herrero, M. 2010. Potential for reduced methane and carbon dioxide emissions from livestock and pasture management in the tropics. Proc. Natl. Acad. Sci., 46:19667-19672.

United Nations. 2017. Population Division 
World population prospects: the 2017 revision, Key Findings and Advance Tables.

Vaclav, S. 2003. The Earth's Biosphere: Evolution, dynamics, and change. MIT Press. P. 107. ISBN 978 - 0 262-69298-4.

Valtorta, S. E., Leva, P. E., Gallardo, M. $R$ and Scarpati, O. E. 2012. Milk production responses during heat waves events in Argentina. 15th conference on Biometeorology and Aerobiology -16th International Congress on Biometerology. Kanas City, MD. American Metrological Society, Boston, pp. 98 -101.

Wright, I. A., Tarawali, S., Blummel, M., Gerard, B., Teufel, N., Herrero, M. 2012. Integrating crops and livestock in subtropical agricultural systems. $J$. Sci. Food Agric. 92, 1010-1015.
Yan, T., Agnew, R. E., Gordon, F. J. and Porter, M. G. 2000. Prediction of methane energy output in dairy and beef cattle offered grass silage-based diets. Livest. Prod. Sci., 64: 253-263

Zhou, Y. and Staatz, J. 2016. Projected demand and supply for various foods in West Africa: implications for investments and food policy. Food Policy. 61:198-212

Received: $12^{\text {th }}$ October, 2020 Accepted: $5^{\text {th }}$ February, 2021 